\title{
М.Е. Сивишкина
}

ФГБОУ ВПО «Российская академия народного хозяйства и государственной службь при Президенте Российской Федераичи. Волгоградский филиал» (Волгоград, Россия)

\section{Техники культурной провокации в исследовании стереотипов любви и семьи в сознании современных студентов}

\begin{abstract}
Представлен ряд диагностических техник, объединенных общим названием культурной провокации. Техники предназначены для выявления субъективных ориентиров построения интимно-личных отночений, в первую очередь образа любви и образа семьи в представлениях студенческой молодежи. Обосновывается релевантность методического подхода. $B$ качестве обоснования привлечено понятие культурного опосредствования высших психических образований человека, содержсащееся в культурно-исторической теории Л.С. Выготского и его последователей. Приведено описание методик и краткое описание полученных результатов исследования. Представлень статистические данные. В качестве результата исследования обоснована разрешающая способность примененных техник, в совокупности позволяющих различать стереотипное и рефлексивное содержание ориентировки в образах любви и семейных отношений, степень причастности сознания респондентов $\kappa$ экзистенциально-смысловой стороне человеческих отношений.

Ключевые слова: стереотип; культурно-исторический подход; культурное опосредствование; техника культурной провокации; дифференцированный выбор; вещно-атрибутивные отношения; интимно-личные отношения; рефлексия.
\end{abstract}

\section{Введение}

Образы любви и семьи относятся к конституирующим основаниям в жизни людей. Поэтому быстрая смена представлений в этой области невозможна и нежелательна, поскольку грозит разрушением общекультурной и этнокультурной трансмиссии и психологической сегрегацией $[1,2]$, а значит, сознание людей в этой области опирается на традиционные стереотипы.

Но наряду с сохраняющимися традициями эта сфера жизни людей, особенно молодых, подвержена влиянию социальной и культурной динамики. Таким образом, можно ожидать, что ориентировка молодых людей в этой сфере может представлять своего рода смесь традиционных и современных ориентиров, не всегда становящуюся предметом осознания и рефлексии. 
Особенность интимно-личной сферы жизни состоит в том, что эта область регламентирована человеческой культурой, но при этом согласно традиции, во многом заданной психоанализом, соотносится - как в сознании психологов, так и в обыденном сознании - с областью низменного и бессознательного. Такое понимание редуцирует интимность к сексуальности и обеспечивает своего рода «алиби» для рефлексивных процессов, признание их неучастия в развитии и становлении человеческой интимности.

«...Сексуальность человека, как и многие другие "низменные" функции, оказалась “теоретической невидимой” для психологии, - пишет Ю.П. Зинченко. - Признавая декларативно психосоматическое единство человека, академическая психология на деле ограничивается в настоящее время преимущественно исследованием разных уровней осознания телесных функций, не замечая, что сексуальность, как и другие телеснье функцчии, в ходе прижизненного формирования в культурной среде теряет свой изначальный природный характер и приобретает качественные изменения, сближающие ее по ряду существенных признаков с так называемыми выстими психическими функциями (курсив мой. - М.С.)» [3. С. 53].

Параллельно с отмеченным «алиби» в отечественной психологии развития, в отличие от психоаналитического направления в зарубежной психологии, произошла «когнитивизация» представлений о человеческой жизни. Сосредоточенность на развитии мышления как главного направления развития позволила создать систему развивающего обучения [4]. Но при этом произошло отделение мышления от переживания, интеллекта от аффекта, несмотря на декларированное Л.С. Выготским [5] их единство.

Если же рассматривать построение интимно-личных отношений в контексте культурно-исторического и деятельностного подходов, то центральным моментом такого рассмотрения должно быть культурное опосредствование или, в более узком значении, - знаково-символическое опосредствование - принятие знака и применение его в качестве средства культурной ориентировки. Представляется, что задачу выявления личностных ориентиров, включающих как стереотипные, так и субъектносубъективные (индивидуально осмысленные) маркеры, можно решать посредством метода «культурной провокации». (Название и принцип построения одной из применявшихся нами техник были заимствованы из работы Е.Г. Юдиной [6. С. 140].)

Под «культурной провокацией» в нашем исследовании понимается следующее.

Человек в интересующей нас области ориентируется посредством множества разнородных представлений о любви, семье, счастье, почерпнутых как из образов обыденного сознания той социальной среды, в которой он вырос, так и из содержания произведений культуры. То, как он реагирует на прототипы этих образов-маркеров, может дать представление о его ориентировке.

Мы предположили, что, предлагая четко структурированные стимулы, основанные на клише обыденного сознания, наряду с неструктуриро- 
ванными стимулами, провоцирующими самостоятельные размышления на тему смысла человеческих отношений, отношений мужчины и женщины, мы «спровоцируем» респондентов проявить либо стереотипную ориентировку, либо индивидуально-личную.

В этом исследовании нас интересовала сама возможность использования «культурной провокации» как средства различения стереотипного отношения к темам любви и семьи и субъективно причастного рефлексивного отношения к этой теме.

Перейдем к описанию методик.

\section{Методика дифференцированного выбора утверждений}

При построении стимульного материала мы исходили из следующих предположений.

Распространенные, банальные, стереотипные характеристики любовных отношений, отношений в семье, мужских и женских, а также родительских ролей сами по себе не требуют от человека сколько-нибудь подробного анализа, не предполагают его. Как правило, эти представления синкретичны. Предлагая определенную градацию между полюсами биполярных конструктов, содержащих банальности, мы тем самым вводили своего рода когнитивное плацебо: эта ориентировка не имеет реальньх оснований, сама по себе, как таковая, она не работает.

И хотя это «пустышка», для нас было важно, как человек ее интерпретирует. Понятно, что ни «предельно романтические», ни «предельно прагматические» представления, равно как и предельно категоричные утверждения о главенстве мужчины или о главенстве женщины в семье, не могут служить надежной опорой для ориентировки в отношениях. И то и другое - фикции, их выбор в качестве характеристик отношений может определяться инфантилизмом или максимализмом, но и то и другое в равной мере - проявления незрелости.

Например, предлагалось определить степень приемлемости для себя утверждений «Полюбить может каждый» и «Не каждый способен любить». Формально эти утверждения противоречат друг другу, но оба они стереотипны, и четкость их дифференцировки не имеет реальной верификации при построении ориентировки в интимно-личных отношениях. Формально романтически-бескорыстная ориентация предполагает выбор первого утверждения, утилитарно-стяжательская - второго. Однако рефлексивно размышляющий человек способен понять, что, несмотря на формальное противоречие, оба они в равной мере соотносимы с фактами человеческого существования и выбирать одно из этих двух не приходится.

Стимульный материал составили 28 пар таких формально альтернативных высказываний.

Испытуемым предлагалось сделать выбор между высказываниями в каждой паре по 5-балльной шкале.

Все высказывания относились к четырем категориям: 
- стереотипные высказывания о понимании любви;

- стереотипные образы мужчин и женщин, образы различий между ними; в семье;

- стереотипные высказывания о различиях ролей мужчин и женщин

- стереотипные высказывания о различиях в исполнении родительских ролей мужчинами и женщинами.

Ниже приведены примеры стимульного материала, разделенные в соответствии с этими категориями. В бланке методики они даны вперемежку.

Т а бли ц а 1

Примеры стимульного материала методики дифференцированного выбора утверждений

\begin{tabular}{|c|c|c|c|c|c|c|c|}
\hline Категории & Утверждения & \multicolumn{5}{|c|}{ Оценка, баллы } & Утверждение \\
\hline \multirow{4}{*}{$\begin{array}{l}\text { Стереотипные } \\
\text { высказывания } \\
\text { о понимании } \\
\text { любви }\end{array}$} & $\begin{array}{l}\text { Настоящая любовь } \\
\text { существует }\end{array}$ & 1 & 2 & 3 & 4 & 5 & $\begin{array}{l}\text { Настоящая любовь - } \\
\text { это выдумка }\end{array}$ \\
\hline & $\begin{array}{l}\text { Полюбить может } \\
\text { каждый }\end{array}$ & 1 & 2 & 3 & 4 & 5 & $\begin{array}{l}\text { Не каждый способен } \\
\text { любить }\end{array}$ \\
\hline & \begin{tabular}{|l|} 
Полюбить можно \\
каждого человека
\end{tabular} & 1 & 2 & 3 & 4 & 5 & Не все заслуживают любви \\
\hline & $\begin{array}{l}\text { Любовь - это всегда } \\
\text { проблема для чело- } \\
\text { века }\end{array}$ & 1 & 2 & 3 & 4 & 5 & $\begin{array}{l}\text { Любовь - это решение } \\
\text { многих проблем }\end{array}$ \\
\hline \multirow{3}{*}{$\begin{array}{l}\text { Стереотипные } \\
\text { образы муж- } \\
\text { чин и жен- } \\
\text { щин, образ } \\
\text { различий } \\
\text { между ними }\end{array}$} & $\begin{array}{l}\text { Мужчина в большей } \\
\text { степени способен к } \\
\text { любви }\end{array}$ & 1 & 2 & 3 & 4 & 5 & $\begin{array}{l}\text { Женщина способна к люб- } \\
\text { ви в большей степени }\end{array}$ \\
\hline & $\begin{array}{l}\text { Мужчина обладает } \\
\text { правом выбора } \\
\text { партнера }\end{array}$ & 1 & 2 & 3 & 4 & 5 & $\begin{array}{l}\text { Женщина обладает правом } \\
\text { выбора партнера }\end{array}$ \\
\hline & $\begin{array}{l}\text { Мужчина по приро- } \\
\text { де свободен }\end{array}$ & 1 & 2 & 3 & 4 & 5 & $\begin{array}{l}\text { Женщина по природе сво- } \\
\text { бодна }\end{array}$ \\
\hline \multirow{3}{*}{$\begin{array}{l}\text { Стереотипные } \\
\text { высказывания } \\
\text { о различиях } \\
\text { ролей } \\
\text { мужчин и } \\
\text { женщин в } \\
\text { семье }\end{array}$} & $\begin{array}{l}\text { В семье мужчина } \\
\text { главный }\end{array}$ & 1 & 2 & 3 & 4 & 5 & В семье женщина главная \\
\hline & \begin{tabular}{|l} 
Роль мужчины в \\
семье - зарабаты- \\
вать деньги
\end{tabular} & 1 & 2 & 3 & 4 & 5 & $\begin{array}{l}\text { Роль мужчины - обеспечи- } \\
\text { вать семью и воспитывать } \\
\text { детей }\end{array}$ \\
\hline & \begin{tabular}{|l} 
Смысл брака - \\
воспитание детей
\end{tabular} & 1 & 2 & 3 & 4 & 5 & $\begin{array}{l}\text { Смысл брака - союз двух } \\
\text { любящих людей }\end{array}$ \\
\hline \multirow{3}{*}{$\begin{array}{l}\text { Стереотипы } \\
\text { выполнения } \\
\text { родительских } \\
\text { ролей }\end{array}$} & $\begin{array}{l}\text { Мужчина не умеет } \\
\text { воспитывать детей }\end{array}$ & 1 & 2 & 3 & 4 & 5 & $\begin{array}{l}\text { Каждый мужчина может } \\
\text { стать прекрасным отцом }\end{array}$ \\
\hline & $\begin{array}{l}\text { Мужчина как отец } \\
\text { всегда мягкий и } \\
\text { внимательный }\end{array}$ & 1 & 2 & 3 & 4 & 5 & $\begin{array}{l}\text { Мужчина как отец требо- } \\
\text { вательный }\end{array}$ \\
\hline & $\begin{array}{l}\text { Женщина-мать - } \\
\text { внимательная и за- } \\
\text { ботливая }\end{array}$ & 1 & 2 & 3 & 4 & 5 & $\begin{array}{l}\text { Женщина как мать } \\
\text { требовательная }\end{array}$ \\
\hline
\end{tabular}




\section{Метафорическая история «Два предмета»}

Мы предлагали написать историю о том, что может произойти с двумя хорошо знакомыми предметами. Более инструкция никак не комментировалась и не уточнялась. Мы предполагали, что неопределенность стимула, низкая интервентность техники позволят получить некоторый диапазон фабул, в которых будет представлена и тема интимных отношений.

Для нас было важно, в каком направлении будут ориентированы ассоциации и что составит основную интригу текстов. Интерпретацию стимула, его превращение в фабулу мы условно назвали «транскрипцией», понимая под этим перевод задания в форму его субъективного понимания респондентом. При этом мы предполагали, что поскольку построение интимно-личных отношений входит в актуальную возрастную задачу [7] наших респондентов, вероятность развития темы в этом направлении достаточно велика, чтобы предложение написать такую историю сработало как культурная провокация. Тем более что другие варианты этой техники уже были апробированы в работах коллег $[8,9]$ и наших предшествующих исследованиях $[10,11]$.

\section{Дифференцирующий выбор «Образы любви»}

В этой технике использовались «плакатные», «клиповые» образы, прототипы которых составляют практически неразрывный видеоряд, предлагаемый современной поп-культурой, кино и рекламой. В качестве стимульного материала мы использовали фотографии, найденные в Интернете. Из общего массива изображений (30 снимков), отпечатанных на карточках формата $10 \times 15 \mathrm{~cm}$, респондентам предлагалось выбрать те, которые, по их мнению, отражают представление о том, что такое «любовь», а затем обосновать свой выбор.

При составлении техники дифференцирующего выбора «Образы любви», собрав полный набор картинок для стимульного материала, мы сгруппировали 11 семантических категорий. Далее в этой статье мы приведем лишь несколько самых выбираемых респондентами категорий.

Проективная техника «Продолжение сказки». Респондентам предлагалось написать собственный вариант продолжения известной сказки Ш. Перро «Спящая Красавица», придерживаясь следующей инструкции: «Напишите любое возможное, на Ваш взгляд, продолжение сказки о Спящей Красавице».

При использовании этой техники, так же как и при использовании техники «Два предмета», мы предполагали рассматривать эффекты «транскрипции»: то, в каком направлении и по какой событийной логике будет разворачиваться фабула.

Последовательность применения методик определялась чередованием дифференцированных выборов и относительно свободных эпистолярных техник, допускающих ассоциирование и фантазирование. Такое чере- 
дование позволяло нам ожидать, что у респондентов есть повод предположить общий контекст исследования и ассоциировать его с темой интимноличных отношений.
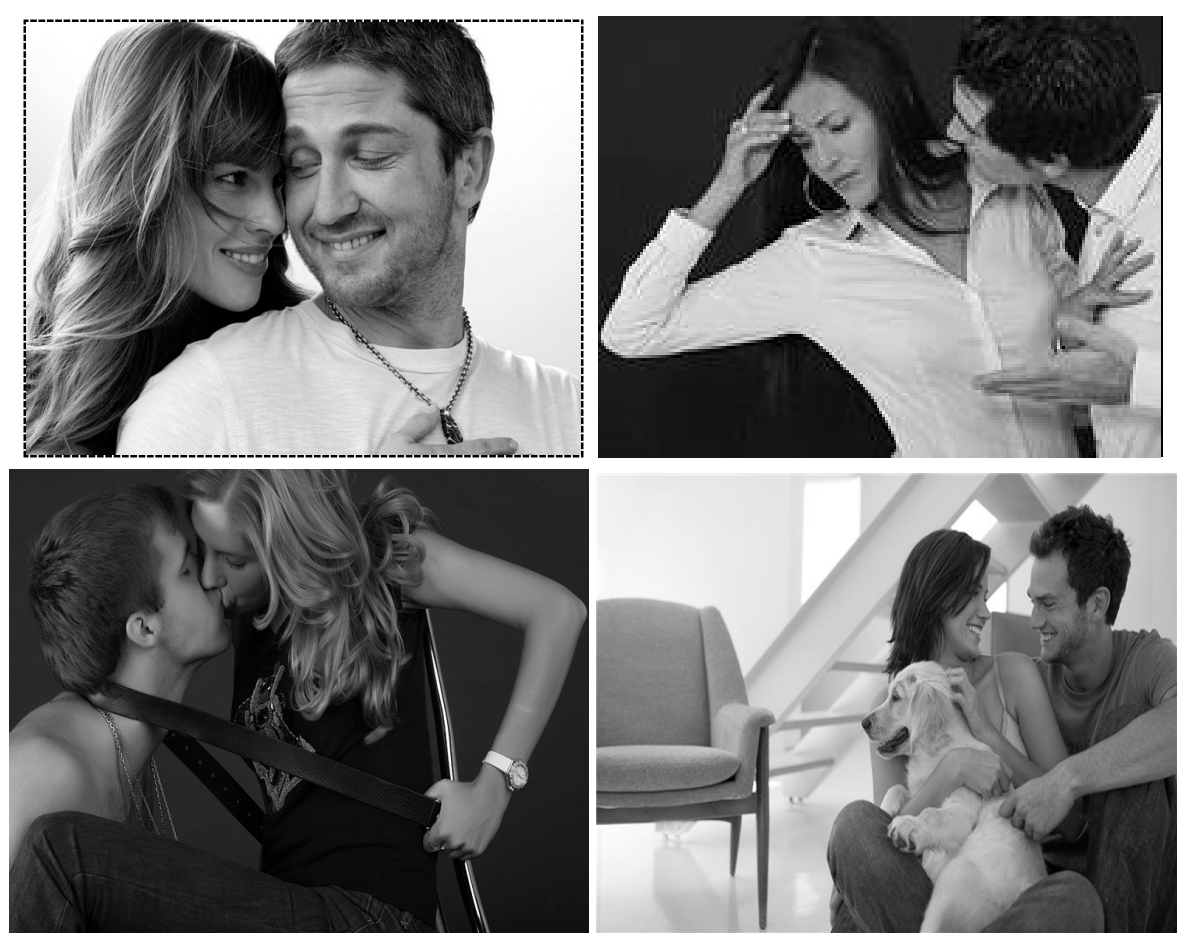

Рис. 1. Примеры снимков, используемых в методике дифференцирующего выбора «Образы любви»

\section{Результаты исследования}

Приведем результаты исследования, обобщенные по всем использованным техникам. В исследовании приняли участие 417 человек, студентов Волгоградского филиала РАНХиГС в возрасте от 17 лет до 21 года, 148 юношей и 269 девушек.

При использовании дифференизиованного выбора среди стереотипных утверждений, которые предположительно играли роль «когнитивного плацебо», ответы респондентов мы разделяли на «серединные» и «крайние». Поскольку утверждения были объединены в формально противоречивые пары, но при этом каждое из них было стереотипно, понимание этой реальности предполагало нейтральный - «серединный» выбор или небольшое отклонение от него. Также мы предполагали возможность аргументированного отказа от выполнения задания.

В качестве формального критерия выступал следующий. К «серединной» группе респондентов мы отнесли тех, кто вовсе не выбирал край- 
ние позиции ни по одному биполярному конструкту, ограничиваясь коридором «2 - 3-4», либо делал это (т.е. выбрал значения «1» или «5») не чаще чем в 6 случаях (менее $25 \%$ от общего числа конструктов).

В результате мы не получили ни одного отказа; только $0,7 \%$, т.е. трое респондентов, сделали абсолютный выбор в пользу «серединных» вариантов; 14,8\% респондентов разделили свой выбор между «крайними» стереотипными формами и «серединными» вариантами. Они были нами условно отнесены к «серединным» по описанному выше формальному критерию. У 85,2\% респондентов в выборе преобладали «крайние», т.е. стереотипные маркеры. Распределение этих выборов по категориям представлено в табл. 2 .

Т а б ли ц а 2

\section{Примеры преобладающих «крайних» выборов (по категориям)}

\begin{tabular}{|c|c|c|}
\hline Категории & Утверждение & $\begin{array}{c}\text { Процент выбора } \\
\text { категории от об- } \\
\text { щего числа ре- } \\
\text { спондентов }\end{array}$ \\
\hline \multirow{4}{*}{ Любовь } & Настоящая любовь существует & 74,2 \\
\hline & Полюбить может каждый & 55,3 \\
\hline & Полюбить можно каждого человека & 44,9 \\
\hline & $\begin{array}{l}\text { Любовь предполагает одного-единственного } \\
\text { спутника на протяжении жизни }\end{array}$ & 57,8 \\
\hline \multirow{4}{*}{$\begin{array}{l}\text { Мужчины и } \\
\text { женщины }\end{array}$} & Мужчина - сильный, ответственный & 80,5 \\
\hline & $\begin{array}{l}\text { Женщина - привлекательная, эмоциональная, } \\
\text { сексуальная }\end{array}$ & 47,5 \\
\hline & $\begin{array}{l}\text { Мужчина - логичный, амбициозный, целе- } \\
\text { устремленный }\end{array}$ & 54,2 \\
\hline & Женщина - активная, целеустремленная & 35,6 \\
\hline \multirow{3}{*}{$\begin{array}{l}\text { Роли мужчин и } \\
\text { женщин в семье }\end{array}$} & В семье мужчина главный & 62,3 \\
\hline & $\begin{array}{l}\text { Роль мужчины - обеспечивать семью и воспиты- } \\
\text { вать детей }\end{array}$ & 50,1 \\
\hline & $\begin{array}{l}\text { Роль женщины в семье - рожать и воспитывать } \\
\text { детей }\end{array}$ & 49,7 \\
\hline \multirow{3}{*}{\begin{tabular}{|l} 
Родительские \\
роли мужчин \\
и женщин \\
\end{tabular}} & Каждый мужчина может стать прекрасным отцом & 58 \\
\hline & Мужчина-отец - строгий и требовательный & 38,9 \\
\hline & Женщина-мать - внимательная и заботливая & 69,3 \\
\hline
\end{tabular}

Таким образом, самыми популярными категоричными утверждениями стали:

- «Настоящая любовь существует» - в категории «Любовь»;

- «Мужчина - сильный, ответственный» - в категории «Мужчины и женщины»;

- «В семье мужчина главный» - в категории «Роли мужчин и женщин в семье»;

- «Женщина-мать - внимательная и заботливая» - в категории «Родительские роли мужчин и женщин». 
Такое преобладание «крайних» вариантов в выборах респондентов позволило нам предположить, что их ориентировка в значительной мере стереотипизирована и ее регуляторами могут быть клише обыденного сознания.

Вернемся к «серединной» группе, в которую мы включили 14,8\% респондентов, и возможному основанию их противопоставления группе «крайних». Троих респондентов (юноша 19 лет, юноша 17 лет, девушка 17 лет), продемонстрировавших «центристскую ортодоксию», мы отнесли в отдельную группу, поскольку мотив их выбора был неясен, но мог означать и предполагавшуюся нами форму отказа от выполнения задания.

Мы предположили, что сознательное, рефлексивное отношение к проблеме могло отразиться на «серединном» ее видении. Выбор «крайних» позиций мог отражать категоричное, предвзятое или импульсивное, а в целом нерефлексивное отношение: ведь несовместимость крайних выборов, сделанных по разным позициям опросника, несводимость их в единое гармоничное отношение может объясняться именно отсутствием рефлексии.

Если принять различие между «серединными» и «крайними» выборами за показатель рефлексии и, соответственно, ее отсутствия, то далее можно предположить ориентацию респондентов на содержательно-рефлексивное или, напротив, формально-рассудочное отношение к проблеме.

Различая эти формы отношения, мы ориентировались на работы В.В. Давыдова [12] и его школы, в которых обоснованы различия между содержательно-рефлексивной формой мышления и рассудочноутилитарной. В первом случае предполагается, как говорил В.П. Зинченко [13], «выход в вертикаль сознания» и использование культурного опосредствования для понимания предмета мысли и переживания. При этом анализируется природа проблемы, ее источник. Во втором случае сознание скользит по поверхности явлений, удерживая лишь очевидное, оно опирается не на анализ, а на внешнее сравнение. Тогда, применительно к предмету нашего исследования, в первом случае интимно-личные отношения могут рассматриваться как драма двух индивидуальностей, а во втором как утилитарная задача обретения социальной и материальной выгоды, престижа и благополучия.

Это предположение мы проверяли в следующей части исследования.

Для анализа результатов, полученных посредством эпистолярной техники «Два предмета», мы прибегли к предварительной независимой экспертной оценке всего массива полученных текстов. Ее целесообразность определялась тем, чтобы минимизировать влияние наших собственных исследовательских и личных установок, в том числе влияние ожиданий, сложившихся при анализе результатов дифференцированного выбора. В качестве экспертов были приглашены преподаватели и аспиранты кафедр психологии волгоградских и московских вузов - 8 человек. В их задачу входило распределить все тексты на группы и дать каждой группе обобщенное категориальное определение. При некотором расхождении в категоризации большинство экспертов (6 человек) предложили несколько 
аналогичных или синонимичных категорий. Двое экспертов предложили слишком формальные основания, принципиально отличающиеся от всех остальных и не согласующиеся с нашим видением проблемы.

Расхождение в принятых нами экспертизах относилось к дробности категорий. Мы выбрали наиболее обобщенные, под которые эти дробные могут быть подведены.

В результате мы воспользовались конструктом «утилитарно-вещные отношения - человеческие отношения». Внутри этого конструкта мы определили некоторые градации, обозначив категориально направления транскрибирования при выполнении задания:

- вещно-натуралистическая транскрипция;

- самопрезентация, нарциссизм;

- вещно-утилитарная, рыночная транскрипция;

- отношения как проблема;

- отношения «человек - человек».

Приведем краткую характеристику этих категорий и соответственно отнесенных к ним текстов респондентов.

Вещзно-натуралистические: предметы представлены натуралистично, описаны события, которые можно наблюдать непосредственно или нетрудно придумать, не строя сколько-нибудь разработанной метафорической фабулы.

«Ручка писала на листочке» (М. 18).

«Карандаш и ластик на коние» (М. 19).

«Стол и стул всегда находятся вместе, они не могут друг без друга, они всегда помогают и поддержсивют друг друга» (Ж. 19).

Самопрезентация, нарииссизм: задание переформулируется авторами в возможность рассказать что-то о себе, поэтому предметы в этих текстах приобретают «притяжательное значение», и именно оно определяет фабулу - описываются предметы, когда-то купленные, полученные в качестве подарка. Предлагаемое название «Два предмета» транскрибируется в «Мои два предмета» или «Два интересных предмета в моей жизни». В этих текстах натурализм как бы удвоился: респонденты написали о себе натуральных и принадлежащих им натуральных предметах.

« меня есть часы, кот. мне очень нравятся. У них довольно насыщенная история. Это была первая дорогая вещь, кот. я купил на свои деньги. С ними я бывал в разных городах и по возможности всегда ному их с собой.

История моего кошелька довольно интересна. Эту вещь я сделал сам. Я сам подбирал кожу, нитки и замок. Сам кроил и шил. Для меня эта вещьь очень ценна» (М. 20).

Тексты, отнесенные к этим категориям, с темой нашего исследования никак не связаны. Тексты, отнесенные к трем оставшимся категориям, содержали искомую транскрипцию: предметы в них одушевлены и превращены в персонажей, для которых отношение с другим предметом явно ассоциируется с интимностью, браком и пр. 
Вещзно-утилитарные, рыночные: предметы представлены не только своей функциональной стороной, но и с точки зрения потребительной, рыночной стоимости, для которой важен «лейбл», «фирменное происхождение», конкурентоспособность. Отношения персонажей строятся на маркетинговой (в понимании Э. Фромма [14]) основе, исходя из полезности, социальной и материальной значимости.

«Жила-была 1000-я купюра. Любила она другую 1000-ю купюру. В один день они поженились и образовали 1000000» (Ж. 18).

«Однажды в продуктовый магазин привезли новую партию шоколада Ritter Sport. На полку вместе попали Ritter Sport (девочка) и Alpen Gold (мальчик). Они стояли вместе, такие красивые, такие влюбленньее. "Но они никогда не смогут быть вместе”, - грозным голосом объявил отеи Alpen Gold. Eму уже была подобрана невеста из их партии шоколада. Так шоколадка Ritter Sport вылила замуж за шоколадку из своей партии, а Alpen Gold женился на шоколадке из своей. И всю жизнь они прожили любя друг друга, но никогда не были вместе» (Ж. 18).

«Девушка пошла в ТЦ, чтобы купить себе сумку. Сумок было много. Но ничего ей не подходило. Roberto Cavalli не подходила к фигуре. Louis Vuitton не подходила к сапогам. Marc Jacobs не подходила к куртке и выглядела слишком агрессивно, Versace, судя по всему, была вовсе и не Versace.

И тогда девушка поняла, что никогда не выберет себе сумку. Потому что сумка должна подходить не к сапогам и не к куртке. Сумка должна подходить к кошельку, точнее к тому, что в нем лежит. В этом мудрость жизни.

Сумка и кошелек, кошелек и банковская карта в нем. Они такие разнье, но так хорошо, когда живут вместе и подходят друг другу» (Ж. 21).

Отношения как проблема: фабула двух предметов прямо транскрибируется в тему интимно-личных отношений, и эти отношения предстают своей проблемной стороной: актуализируются темы разлуки и встречи; измены и ревности; неравенства, несимметричности отношений и проблемы манипуляции, эгоизма и предательства.

«Жили на свете вешалка и пальто. Пальто утром уходило на работу, а вешалка висела и ждала его преданно. Правда, пальто было не очень преданным и вернылм, и приходило домой не всегда вовремя. Вешалка всегда переживала за пальто, обижалась, и когда пальто все-таки приходило, то она одергивала свои плечики, не давала пальто обнять себя. Только после долгих мучений пальто все-таки удавалось добиться прощения вешалки. Оно обнимало ее за тонкие плечи, и они погружались в глубокий, спокойный сон» (Ж. 17).

Отношения «человек - человек»: фабула транскрибируется в обсуждение экзистенциальных проблем - любви и смерти, проблемы растворения в любви, угрозы потери идентичности и проблемы поиска смысла интимных отношений.

«Жил-был ноль. И была его жизнь в цуарстве циифр очень грустна и одинока, потому что в отношения деления и умножения с ним никто не 
вступал. И думал ноль, что жизнь его так и останется одинокой и грустной без друзей циифр. Но тут вдруг он повстречал числовую прямую, которой не хватало одной циифры (и мы знаем какой). Были циифры отрицательные и положительные, но все было в беспорядке, за 1 следовало 20, далее 100. Числовая прямая уже давно пыталась поставить их по порядку и правильно, но ей это не удавалось. И вот вдруг ей встретился грустный ноль. И она поняла, кого ей не хватало, как только ноль встал посередине всех циирр, числовая прямая сразу выставила цифры в правильный ряд. С тех пор у ноля появились новые друзья и числовая прямая его всегда подбадривала и помогала ему (познакомила с графиком)» (М. 18). табл. 3.

Распределение текстов в выборке респондентов представлено в

Посредством техники выбора снимков «Образы любви» было выявлено, что доминирующий образ - это семья, объединяющая родителей и нескольких детей, а также имеющая глубокую, продолжительную жизненную перспективу, что нашло выражение в частых выборах изображения пожилых супругов (табл. 4).

Таблица 3

Процентное распределение текстов «Два предмета» по категориям

\begin{tabular}{|l|c|}
\hline \multicolumn{1}{|c|}{ Категории } & $\begin{array}{c}\text { Процент выбора категории от общего } \\
\text { числа респондентов }\end{array}$ \\
\hline Вещно-натуралистические & 35 \\
\hline Самопрезентация, нарциссизм & 1,8 \\
\hline Утилитарно-вещные, рыночные & 33,3 \\
\hline Отношения как проблема & 18,9 \\
\hline Отношения «человек - человек» & 4,9 \\
\hline $\begin{array}{l}\text { Другое, несопоставимое с выбранными катего- } \\
\text { риями }\end{array}$ & 6,1 \\
\hline
\end{tabular}

Таблица 4

Процентное распределение выбранных категорий в технике «Образы любви»

\begin{tabular}{|l|c|}
\hline \multicolumn{1}{|c|}{ Категории } & $\begin{array}{c}\text { Процент выбора категории от общего } \\
\text { числа респондентов }\end{array}$ \\
\hline $\begin{array}{l}\text { «Счастливая старость»- изображение пожилых } \\
\text { супругов }\end{array}$ & 22,6 \\
\hline «Семья»- супруги-родители с детьми & 22 \\
\hline «Свадьба»- изображения молодоженов & 17,5 \\
\hline $\begin{array}{l}\text { «юбовь двоих»- изображение обращенных } \\
\text { друг к другу мужчины и женщины с явной эмо- } \\
\text { цией взаимной симпатии }\end{array}$ & 11 \\
\hline $\begin{array}{l}\text { «Мать и дитя»- изображение женщины-матери } \\
\text { с ребенком }\end{array}$ & 15,9 \\
\hline Другое & \\
\hline
\end{tabular}


В завершение представим результаты, полученные посредством техники «Продолжение сказки». Особенность данной техники состояла в том, что предполагалась некоторая предопределенность «сказочного» продолжения, в большей степени провоцирующая стереотипную форму ответа. (В истории «Два предмета», напротив, такая провокация отсутствовала.) Но у респондентов оставалась возможность выбора собственного продолжения сказки: оставаться ли в границах известной фабулы или преодолевать инерцию стереотипа. В результате $17,8 \%$ респондентов составили авторские продолжения; 82,2\% респондентов представили стереотипные «сказочные» продолжения.

Пример стереотипного продолжения истории:

«Дальше они жили прекрасно. У них были двое прекрасных детей, мальчик и девочка. Жили они долго. Прини правил как настоящий король, все его любили. Принцесса была любящей и доброй женой. И все у них было очень хорошо!» (М. 18).

Пример оригинального авторского продолжения:

«Спящая Красавица наконещ-то проснулась! А когда она проснулась, она увидела горы немытой посуды, грязного белья, неубранный дом и орущих детей и мужа, сидевшего на диване и смотрящего футбол. Проснувшейся Красавице это не понравилось. Она представила, сколько времени и сил ей понадобится, чтобы все убрать. Поэтому она выбрала свой путь выпила снотворного и снова стала Спящей Красавищей» (М. 18).

\section{Итоги исследования:}

1. В исследовании использовались диагностические техники, которые мы объединили общим названием «культурная провокация», понимая под этим обращение к респондентам со структурированными и неструктурированными стимулами, провоцирующими экспликацию и актуализацию культурных опосредствований, используемых при ориентировке в сфере интимно-личных отношений: любви мужчины и женщины, их отношений в браке, их позиций в семье.

2. Посредством методики дифференцированного выбора утверждений мы разделили выборку респондентов - 417 человек, 148 юношей и 269 девушек в возрасте от 17 лет до 21 года - на группу «серединных» 129 и группу «крайних» - 285 человек. Трое респондентов, как мы уже отмечали, были выделены в особую группу.

По нашему предположению, у группы «серединных» умеренность выбора среди несовместимых категоричных утверждений могла быть связана с рефлексивным пониманием проблемы интимно-личных отношений.

Представители группы «крайних», по нашему предположению, напротив, могли быть склонны к стереотипным клише, не проблематизируя построение отношений, не подвергая ориентировку в них рефлексии.

Предполагалось, что респонденты, отнесенные нами к этим группам, будут различаться по качеству ответов на последующие культурные провокации. Так, мы предположили, что при написании истории «Два предмета» представители «серединных» могут дать более взвешенные и субъек- 
тивно окрашенные реакции и тем самым их тексты будут соотносимы с категориями «Отношения как проблема» и «Отношения “человек - человек”». Напротив, представители «крайних», могли отреагировать на провокацию непосредственно, и их тексты будут относиться к категориям «Вещно-натуралистические описания», «Самопрезентация» и «Утилитарно-вещные, рыночные отношения».

В результате сопоставительного корреляционного анализа по критерию Спирмена нами было получено следующее.

Была установлена положительная связь между попаданием в группу «серединных» и соответствием текстов категории «Отношения как проблема» $(\mathrm{r}=0,279 ; \mathrm{p} \leq 0,05)$.

Была выявлена положительная связь между отнесением к группе «серединных» и соответствием текстов категории «Отношения “человек человек”» $(\mathrm{r}=0,298 ; \mathrm{p} \leq 0,01)$. Также была проверена возможность связи принадлежности к «серединным» с другими категориями. В результате связи с «Вещно-натуралистическим описанием» и «Самопрезентацией» предстали как статистически незначимые, а связь с категорией «Утилитарно-вещные, рыночные отношения» - статистически значимыми $(\mathrm{r}=0,228$; $\mathrm{p} \leq 0,05)$.

Определилась значимая связь между попаданием респондентов в группу «крайних» и отнесением их текстов о двух предметах с категориями «Утилитарно-вещные, рыночные отношения» $(\mathrm{r}=0,257 ; \mathrm{p} \leq 0,05)$ и «Вещно-натуралистическая транскрипция» $(\mathrm{r}=0,229 ; \mathrm{p} \leq 0,05)$.

Значимых корреляционных связей между попаданием в группу «крайних» и категориями «Самопрезентация», «Отношения как проблема» и «Отношения “человек - человек”» не выявлено.

3. В дальнейшем при работе с фотоснимками респонденты «серединной» группы на статистически значимом уровне делали выбор в пользу категории «Любовь двоих», причем выбирали снимки как с позитивным $(\mathrm{r}=0,257 ; \mathrm{p} \leq 0,05)$, так и с проблемным (конфликтным) содержанием $(\mathrm{r}=0,259 ; \mathrm{p} \leq 0,05)$.

Респонденты группы «крайних» в большей мере ориентировались на позитивные-беспроблемные сюжеты «Семья - супруги-родители с детьми» $(\mathrm{r}=0,233 ; \mathrm{p} \leq 0,05)$, «Свадьба» $(\mathrm{r}=0,229 ; \mathrm{p} \leq 0,01)$ и «Счастливая старость» $(\mathrm{r}=0,228 ; \mathrm{p} \leq 0,05)$.

4. Также была установлена значимая корреляционная связь между попаданием в категорию «крайних» и написанием «стереотипного» продолжения сказки $(\mathrm{r}=0,356 ; \mathrm{p} \leq 0,01)$.

При соотнесении результатов группы респондентов, обозначенной выше «центристской ортодоксией» (респонденты выбрали «серединные» ответы на все представленные вопросы методики дифференцирующего выбора утверждений), можно отметить проявление личностных защитных реакций, выраженный «отказ» от выполнения задания (у 2 из 3 респондентов), а третий респондент выполнил задание не в соответствии с инструк- 
цией, поэтому его результаты недействительны в рамках данного исследования.

В целом исследование подтвердило релевантность метода культурной провокации в отношении к предмету исследования.

\section{Лuтература}

1. Мартиросян К.B. Суверенность личного пространства как предмет теоретического и эмпирического психологического исследования // Науковедение. 2013. Вып. 6. URL: http://naukovedenie.ru/PDF/65PVN613.pdf

2. Мартиросян К.В. Этноспецифичность суверенности психологического пространства личности // Современные проблемы науки и образования. 2014. № 6. URL: http://www.science-education.ru/pdf/2014/6/989.pdf

3. Зинченко Ю.П. Философско-психологические аспекты изучения репродуктивной функции // Вестник Московского университета. Сер. 7. Философия. 2003. № 5. C. 53-61.

4. Давыдов В.В. Теория развивающего обучения. М. : ИНТРОР, 1996. 544 с.

5. Выготский Л.С. Проблема умственной отсталости // Собрание сочинений : в 6 т. Т. 5 : Основы дефектологии / под ред. Т.А. Власовой. М. : Педагогика, 1983. С. 231256.

6. Юдина Е.Г. Позиция педагогов: авторитаризм и партнерство // Вопросы психологии. 2005. № 4. С. 132-142.

7. Эриксон Э. Идентичность: юность и кризис. М. : Прогресс, 1996. 344 с.

8. Медведев А.М. Ранняя юность: самосознание и жизненная перспектива. Волгоград : Изд-во ФГОУ ВПО ВАГС, 2008. 204 с.

9. Медведев А.М., Судьина И.С. Риски взросления в самосознании молодых людей пятнадцати и двадцати лет // Психологическая наука и образование. 2009. № 2. C. 14-22.

10. Медведев А.М., Сивишкина М.E. Субъектность и личные теории в построении интимно-личного отношения в юношеском возрасте // Психология обучения. 2013. № 6. C. 103-117.

11. Медведев A.M., Сивишкина M.E. Модель акта развития как средство анализа задачи построения интимно-личного отношения // Психология обучения. 2013. № 10. C. $28-43$.

12. Давыдов В.В. Деятельностная теория мышления. М. : Научный мир, 2005. 240 с.

13. Зинченко В.П. Творческий акт и смысл в структуре сознания: (Отчет по Индивидуальному исследовательскому проекту № 07-01-178, выполненному при поддержке Научного фонда ГУ-ВШЭ). URL: http://www.hse.ru/data/682/941/1224/ Зинченко_ВП_творческий_акт_1.doc.

14. Фромм Э. Мужчина и женщина. М. : АСТ, 1998. 512 с.

Поступила в редакииюю 05.02.2015 2.; повторно 21.04.2015 г.; принята 05.05.2015 г.

СИВИШКИНА Маргарита Евгеньевна, аспирант и преподаватель кафедры психологии ФГБОУ ВПО «Российская академия народного хозяйства и государственной службы при Президенте Российской Федерации. Волгоградский филиал» (Волгоград, Россия).

E-mail: Sivmare@mail.ru 
Siberian journal of psychology, 2015, 56, 177-192. DOI 10.17223/17267080/56/14

Margarita E. Sivishkina

Russian Presidential Academy of National Economy and Public Administration. Volgograd branch (Volgograd, Russian Federation).

E-mail:sivmare@mail.ru

\section{Techniques of cultural provocation in the study of family and love stereotypes in students` minds}

The choice of stereotypical images of love and family, which are represented in minds of young people, identifies the search for appropriate methodical receptions as a subject of our research in the context of social psychology. This article presents such techniques united under the title «cultural provocation».

By the cultural provocation we consider a method of introducing as a stimulus stimulus-means in terms LS Vygotsky - verbal concepts and visual images, the content of which in some cases has a strong association with the theme of love and family, in others - on the contrary, is not explicit. The core of the technique is to provoke differentiation of proposed incentives and finish or "transcribe" unspecified incentives to complete the story.

At first, we asked respondents to make a choice among couples of ambivalent stereotypical statements specific to common sense, for example, «Everyone can love» and «Not everyone is able to love». Then we asked them to write a story «Two objects» about things that can happen with two familiar objects. The instruction was not specified. That was followed by the task of making differentiated choice «Images of Love»: it was proposed to the respondents to choose from the set of images (30 images) those images that represents the idea of "love", and then explain their choice. At the end of the process the respondents were invited to write their own version of continuation of the famous Charles Perrault's fairytale «Sleeping Beauty»).

While analyzing the results of method of choice of statements, we have identified two groups of respondents: first group is consisted of respondents whose responses are dominated by extremely categorical stereotypical clichés (a group of «extreme»), the other group of the «middle» choices - includes respondents who chose the average value. Results of subsequent tasks correlated with respondents belonging to one of the groups.

Results: established significant correlations between the allocation to a certain group - «extreme» or «middle» - and the content of the stories about two subjects and the continuations of the tales. Respondents of the «extreme» group presented intimate-personal relationships from utilitarian and status position (market character orientation by Erich Fromm). The continuations of the tale are usually stereotyped in their performance: «Everything is as it should be».

Respondents of the "middle" group presented the problem from the "human human" position: as containing value-existential problem. The continuations of the tale made by those respondents largely contains original plot.

Working with photographs, respondents of the «middle» group at statistically significant level opted for the category «Love of the couple». Moreover, they chose not only positive images, but also images with the problematic (conflicting) content.

Respondents of the «extreme» group are more oriented to the positive, smooth plots: «The family - spouses - parents with children», «Wedding» and «Happy old age». 
In general, this research has confirmed the relevance of the method of cultural provocation in relation to the subject of the research.

Keywords: stereotype; cultural - historical approach in psychology; signsymbolic mediation; technique «cultural provocation»; differentiated choice; proprietary attribute relationships; intimate personal relationship; reflection.

\section{References}

1. Martirosyan, K.V. (2013) The sovereignty of personal space as a subject of theoretical and empirical psychological research. Naukovedenie - Naukovedenie. [Online] 6. Available from: http://naukovedenie.ru/PDF/65PVN613.pdf. (Accessed 5th June 2015). (In Russian).

2. Martirosyan, K.V. (2014) Ethnic characteristics of the sovereignty of the individual psychological space. Sovremennye problemy nauki i obrazovaniya - Modern Problems of Science and Education. [Online] 6. Available from: http://www.scienceeducation.ru/pdf/2014/6/989.pdf. (Accessed 5th June 2015). (In Russian)

3. Zinchenko, Yu.P. (2003) Filosofsko-psikhologicheskie aspekty izucheniya reproduktivnoy funktsii [Philosophical and psychological aspects of the study of reproductive function]. Vestnik Moskovskogo universiteta - Moscow University Bulletin. 7 (5). pp. 53-61.

4. Davydov, V.V. (1996) Teoriya razvivayushchego obucheniya [The theory of developmental education]. Moscow: INTROR.

5. Vygotskiy, L.S. (1983) Problema umstvennoy otstalosti [The problem of mental retardation]. In: Vygotskiy, L.S. \& Vlasova, T.A. Osnovy defektologii [The Basics of Defectology]. Vol. 5. Moscow: Pedagogika.

6. Yudina, E.G. (2005) The teacher's position. Authoritarianism and Partnership]. Voprosy psikhologii. 4. pp. 132-142. (In Russian).

7. Erikson, E. (1996) Identichnost': yunost' $i$ krizis [Identity: Youth and Crisis]. Translated by V. Rivosh, N. Tolstykh, A. Andreeva \& A. Prikhozhan. Moscow: Progress.

8. Medvedev, A.M. (2008) Rannyaya yunost': samosoznanie i zhiznennaya perspektiva [Young adulthood: self-consciousness and vital prospect]. Volgograd: Volgograd Academy of Public Administration.

9. Medvedev, A.M. \& Sud'ina, I.S. (2009) Growing-up Risks in the Consciousness of Young People of Fifteen and Twenty Years Old. Psikhologicheskaya nauka i obrazovanie - Psychological Science and Education. 2. pp. 14-22. (In Russian).

10. Medvedev, A.M. \& Sivishkina, M.E. (2013) Subjectivity and theories of personality in building intimate relations in a teen age. Psikhologiya obucheniya-Psychology of Education. 6. pp. 103-117. (In Russian).

11. Medvedev, A.M. \& Sivishkina, M.E. (2013) A model of an act of development as a mean of analyzing a task of building of intimate and personal relations. Psikhologiya obucheniya-Psychology of Education. 10. pp. 28-43. (In Russian).

12. Davydov, V.V. (2005) Deyatel'nostnaya teoriya myshleniya [The activity theory of mind]. Moscow: Nauchnyy mir.

13. Zinchenko, V.P. (2008) Tvorcheskiy akt $i$ smysl $v$ strukture soznaniya [The creative act and the meaning of the structure of consciousness]. Report on Individual Research Project № 07-01-178, supported by the HSE]. [Online] Moscow: HSE. Available from: http://www.hse.ru/data/447/445/1233/3инченко_ВП_\%20творческий\%20акт_1.doc (Accessed 5th June 2015).

14. Fromm, E. (1998) Muzhchina i zhenshchina [Man-Woman]. Translated from German by S. Barabanov et al. Moscow: AST. 